\section{E A Institute of \\ YK Business Administration \\ 光 \\ Karachi \\ Leadership and Ideas for Tomorrow}

\section{Business Review}

Volume 3 Issue 1 January-June 2008

$1-1-2008$

\title{
Spiritual basis of worldly success
}

Dr. Jur. Menno Adden

Technische Universitöät Dortmund, Germany

Follow this and additional works at: https://ir.iba.edu.pk/businessreview

Part of the Arts and Humanities Commons

(c) (;)

This work is licensed under a Creative Commons Attribution 4.0 International License.

\section{Recommended Citation}

Adden, D. (2008). Spiritual basis of worldly success. Business Review, 3(1), 153-164. Retrieved from https://doi.org/10.54784/1990-6587.1139 


\title{
DISCUSSION
}

\section{Spiritual Basis of Worldly Success}

\author{
Dr. iur. Menno Adden \\ Technische Universitöät Dortmund, Germany
}

\section{POINT OF DEPARTURE}

Dakistan is built not on a long national history, not on a common language or the like. The common bond of Pakistanis is the Islam. The whole country is soaked with religion. For a Western visitor it is both impressing and intriguing to see as to what great extent everybody seems to keep the fasts and does his prayers. It is impressive as we in the West have almost lost this religious fervour. It makes me ask, where we Europeans are bound to go if we lose our Christian religion. On the other hand it is intriguing to see Muslim practising their religion as they do. Now in the holy month of Ramadan, overall speaking, people work less than they normally do, offices are closing by midday and tens of thousand small businessmen, restaurant owners and the like, are virtually laid off during the day and have to make good for their lost turnover in the hours after sun set. So this brings me to the topic of this lecture:

Is there a relationship between religion and economic success or failure?

Pakistan has done very well in some aspects of economy, but fares behind international standards in other fields. The same is true in other Islamic countries. Dubai is a glittering example for economic success - and still we are let with some misgivings about how it has been done there. Economic progress has lately been made in Malaysia, but we see very little of it in e.g. Syria or Morocco. Is there a common trait in the development of Muslim countries? If so, does Islam as religion play a role in this? Are there any links at all between economic worldly success and religious beliefs?

Max Weber (1864 - 1920) raised this question with respect to the conspicuous differences between the progressive protestant and the somehow backward catholic regions of the West. MW today he is mainly known for his treatise on exactly this question: Protestantische Ethik und der Geist des Kapitalismus - Ethics of Protestantism and the Spirit of Capitalism. The essence of this treatise can be put short:

- $\quad$ Protestants are economically more successful than Catholics and followers of other religions

- Worldly success may therefore be somehow connected with being a protestant. 
If we apply this theory to Islam we ask: Is worldly success or failure somehow related to being a Muslim?

\section{PROTESTANTISM}

Protestant is the name for Christian groups and sects which split from the Roman Catholic Church as a consequence of Luther's reformation 1517. The reformation is a religious and thereby also a cultural revolution. It was based on a complexity of causes:

- Political: The middle ages were over. The traditional concept of one Emperor holding the secular, and one Pope, wielding the spiritual power over all peoples of the world had outlived itself and was openly disproved, i.a. by the sheer existence of Islam and the Turkish empire.

- Technical: Gutenberg's invention of printing, around 1450, put books in the hands of the hitherto completely unlearned.

- Cultural: The advancement of learning lead people to ask and answer their own questions and to seek answers not only with the priest, the bible and the church.

- Theological: Luther stood up against blatant misuse of the spiritual powers of the church and thereby sparked off the reformation. Gutenberg's new technique helped to quickly spread this insurrection to all parts of Germany, France, England and elsewhere.

\section{PROTESTANT ETHICS}

\section{UNEARNABLE GRACE}

Max Weber says: Protestant are for religious reasons constantly busy and thereby produce capital Max Weber`s line of argument can be summed up as follows:

Christian teaching is that original sin makes man spiritually unfit for the Kingdom of Heaven. Unless saved by operation of religion (e.g. redemption through Christ), he inevitably will end up in hell.

The Catholic Christian developed dogmas with little or no founding in the scriptures, which all but promised man heaven provided he stayed with the teachings of the church. This was the point, when Luther got stuck with St Paul's word: Römer 3, 28:

Or in the translation of the King James Bible: Therefore we conclude that man is justified by faith without the deeds of the law. Or in Luthers translation: So halten wir nun dafür, dass der Mensch gerecht werde ohne des Gesetzes Werke, allein durch den Glauben. 
Faith was the first step to salvation. But even faith is no guarantee. Salvation cannot be earned. It is a grace of God given to the worthy and unworthy alike. Rituals and formalities, not even prayers and fasting, not pilgrimages nor doing good works or faithful obedience to all religious rites and rules can earn the grace of the Almighty.

Ultimately we are led to the conclusion, that it is irrelevant, whether we pray or not, whether we do good, fast or not, God's majesty will not be forced to grant us pardon for our original sin. So the individual is left to find out by himself, what God wishes him to do and not to do. Most probably God wants him to stay in his place and to be good in his profession.

\section{LITERACY - EQUALITY - RULE OF LAW - DEMOCRACY}

If man is direct to God, he must be able to read the Holy Scriptures. Protestantism therefore insisted right from Luther`s first writings on building municipal schools everywhere for everybody. It is protestant Germany where we find the first laws on compulsory schooling as early as 1598 ( Straßburg/Elsaß). This led to a new curiosity: people, who now could read, wanted to know and judge by themselves, what was going on the world. The first regular newspaper was published in protestant Germany (again Straßburg, 1610) and then in Holland, England. He, who knows, will stop thinking of himself as inferior to others. Knowlegde breeds equality. Nobility step by step lost its monopoly on political power. All this started and was developed in the protestant regions of Europe. Thus reformation led to the age of enlightenment. Inasfar catholic scholars, French and few Italian, took part in this all European process, their Catholicism was imbued by protestant thinking and had come very close to agnosticism, if we think of Diderot $(1713$ - 84). Enlightenment (German: Aufklärung) therefore was basically a protestant affair in which now English and Scottish scholars took a leading role and which came to an glorious fulfilment with Immanuel Kant ( 1724 - 1804). Enlightenment was about reason. (German: Vernunft). Kant not only wrote about freedom of thought but almost preached it. Famous are his words:

Enlightenment will be brought about by freedom (Freiheit) under the most harmless aspect of whatever may be called freedom, namely the freedom to openly make use of one`s reason (Vernunft) in all areas of life.

As this freedom directly leads to what we understand as self determination of the individual and also of peoples it follows that there is a direct line from reformation over enlightenment to modern ideas of democracy and even human rights.

A further consequence of reformation was the following: If everybody from peasant to King is direct to God, if we are all equal in his eyes - what difference should there be among fellow creatures? If there are to be any differences these must be 
justified by objective reasons. This led to a new concept of the rule of law. The law is the foe of corruption. Is it just a coincidence that protestant countries are widely considered as corruption free? Law and equality leads to new forms of government. So another fruit of Protestantism is modern parliamentarianism and democracy.

\section{PREDESTINATION/ PREDETERMINATION}

God is all knowing. He knows the past and the future. The Almighty therefore has knowledge on my state of salvation before I even make my first breath. If this is so what can I do? God's grace will be bestowed on me or not - just as he wills. This situation, so Max Weber's argument goes, would make a man anxious and to continuously tremble, whether or not he belongs to the chosen flock. This leads to a state of mind, where he tries to dampen his anxiousness by being constantly busy. If he tries by his own industriousness to help himself, God also may help him - and this then could be a sign that God has chosen him.

Man therefore is like a student who has written a test. It is now beyond his reach to influence its result. He may now be very uneasy for some time until the result is there. To overcome this uneasiness, he can put himself to working so hard that he forgets about it and while doing so he may gain further insight into the topic of his test, and he may feel that his test should be all right.

\section{PREDESTINATION IN ISLAM}

Islam also knows predetermined destiny (qada). If predetermination has effects as described on Protestants, why not on Muslim? Max Weber's arguments would be as applicable to the one as for the other. Actually Max Weber`s theory seems to be applicable at least partly to the early Islamic period.

Why then did Muslim countries develop so differently from the protestant? The holy book, the Quran, had been written down by Zaid ibn Thabit. A good Muslim was expected to read it, because he should understand it by himself. Illiteracy therefore is not a Quranic virtue! So everything was set to let the Muslim countries develop in almost in the same way as later on did the protestant countries.

There are in whole history only few, if any, examples of men so courageous, active and self reliant as where the prophet and his first followers. Out of nothing they built within few decades one of the biggest empires ever. These men were everything, but they were not fatalistic dreamers. The Prophet and his companions put their faith in God, who had spoken to them in the Quran. They were men of action. They wanted to prove to themselves and to the world that they were worthy tools of Allah. They believed in man`s responsibility for his deeds. They did not engage in religious speculations. Rules and rites, regular prayers, fasting etc to them were ways to 
internalise religion, they were not regarded as being the gist of religion. Then in the light of the religion of the Quran the Muslim world developed one of the most splendid periods of world culture. Fatalism, which in the West is often seen as one of the main characteristics of Islam, may be a later distortion of Islam, as is often said. Nevertheless somehow fatalistic ideas became an essential part of the creed of the masses.. ...Mysticism bred fatalistic tendencies it also encouraged indifference to social morality. ...The neglect of social and practical ethics cancelled all programs of humanitarian activity...science disappeared. This neglect and fatalistic state of mind apparently has led to leaving the masses illiterate.

There are may reasons for the decline of the Muslim world. Arguably the Mongolian conquest of Central Asia and the annihilation of the caliphat (1258) most the single most important of them all. The teachings of the Quran, however, are not among them. Islam, so it is said, is the very negation of fatalism. But apparently qada did not remain the driving force in Islam. To the contrary. It was misunderstood as passive acquiescence and surrender to the flow of events which is neither knowable nor predictable. Thus, the attitude requisite for technology.. is absent in popular Islam.

\section{NEW UNDERSTANDING OF NEW TESTAMENT UNDER PROTESTANTISM}

Jesus tells the following parable (Matth. 25, 14ff):

A master went on a long journey. He called his servants. To A he gave 1000 pounds of gold; to B 2000 and to C 5000. Master comes back. A returns 1000 pounds and says: Master, I know your harshness, I was afraid of losing your gold, so I hid it - here it is! B returned 2000 and in addition some profit made with it. . C, who had received most, returned the gold plus the huge profit. The master scolded A: Once you knew that I am harsh - how could you dare to return my gold without even trying to put it to the money lenders and earn some interests on it. B fared somewhat better. C, however, was praised. You are indeed my faithful servant. From now on you shall my steward in greater things. And the master took the gold from $\mathrm{A}$ and gave it to $\mathrm{C}$, who already had so much.

For Protestants this parable has become something kind of a "leading case". The Lord gave to each of us certain talents, If we do nothing more with our talents than just refraining from sins, if we live a life in all decency - this - such is the message of this parable - is not, what the Lord expects from us. We are deceiving the Lord for the profit, we could have earned with the talents he bestowed upon us. St. Luke 12, 48 reports a saying of Jesus: For unto whomsoever much is given, of him shall be much required. So Jesus says: If we are hiding our talents, not using them in the 
furtherance of the Kingdom of God, we are committing a grave sin, even if we return our talents received unimpaired to the Lord.

MW rightfully sees a new understanding of professional life evolving with the reformation. If all men, irrespective of who they are and what they are, depend on the grace of God, they sure are equal before God; if so there should also be equality among men here on earth. Whatever a man does, be he pope or peasant, it is a service to God, which he owes to the Lord in his respective profession. The only thing that counts is: has he performed well in his respective profession? We sing a hymn Lutheran services saying: Oh Lord, give that I do the work in the profession you have assigned me to diligently and at the right time, and let it be done successfully.

\section{ISLAM}

\section{ISLAM AND CHRISTIANITY}

The core problem of every religion is the question: What can /should man do, to become befriended with the Almighty? In Christianity and Islam this question is asked more specifically: What must we do or omit, in order to be accepted to paradise?

It is well known that Islam and Christian religion have many things in common. Islam also knows about the concept of original sin. In Islam the problem of man's free will ( i.e. whether at all he is able to choose between good and bad) has been discussed with almost the same arguments as in Christianity. If God is good, how come, that his creature is bad and needs salvation? If man sins, why should he be punishable, if he follows the path of truth why should he be rewarded? God created him exactly as he happens to be. And after all - what is a sin? The concept of man's punishment and reward would then lead to the heretic assumption, that there is within man's nature something beyond the Almighty's reach, something what he did not create and still it is there. This type of rationalistic thinking came up very soon after the emergence of Christianity and Islam respectively. The Islamic sect of Mutazilism (8th century) seems to ask the same questions and apparently comes up with about the same answers as the Christian Pelagius and his sect did in the $5^{\text {th }}$ century.

Both sects have been refuted by their respective orthodox theologians, who for the Christians are personified in St. Augustine. The orthodox and until today prevailing answers in both religions, Christianity and Islam, to these question also seem to be very similar. God created everything and what he created, was good. God cannot do any evil. The Bad as such does not really exist, it is only the negation of the Good, privatio boni. Bad is what is left over, when we take away the Good. This seems to be also the stance of Islam. The Quran says that God created man with a bias towards the good ( S. 82, 7). This Good, which is found in man's soul, is implanted 
by God, it is his gift. If we subtract this gift from man's soul, then his pure nature lies before us, and this nature has a tendency to be bad. So whatever evil a man does, this comes from his own soul $(\mathrm{S} .4,79)$. So also under Islam man is saved only by grace of God. For Christians God's grace has been bestowed on us through Jesus Christ. The traditional view of the Catholic Church says: this Grace of God is administered by us, the church, you as an individual must not worry. If you follow the teachings of the holy Catholic Church you will not be lost in the final judgement.

For the Muslim this grace of God has been given by sending down the Quran. If man follows the teachings of Quran in good faith he can be all but certain that he will be allowed to enter paradise. It could therefore be said, that the Quran in its entirety for the Muslim has the same function as the church has for the catholic Christian.

\section{ISLAM AND PROTESTANTS}

It is not easy to draw the line between Catholics and Protestants. Bar one big point: The catholic "believes" in the church as an institution said to have been found by Christ himself. The church has the exclusive authority to, as has been said, administer god's grace and thereby to guide man to God and paradise. This concept (extra ecclesiam non est salus = without the church there can be no salvation) was of fundamental importance; it still is, albeit slightly adapted to the facts of the world. The good catholic Christian is expected to content himself with what the Church teaches. It seems that this comes rather close to the Islamic doctrine of taqlid, by which the Muslim passively accepts the teaching of authorities without asking questions.

Luther and reformation questioned this doctrine. According to Luther man is direct to God. Priest and church may help him to understand the Holy Scriptures, but they are no mediators between him and God. It is the privilege and duty of everybody to understand the Holy Scriptures by himself. In this Protestantism is very similar to Islam.

But there remains a difference. Protestantism did overcome taqlid, Islam not yet. True, there are Islamic writers fighting the doctrine of taqlid, but it is still dominant in Islam. It would be tantamount to an Islamic "Reformation", if the doctrine of taqlid came to an end. This would open the door to apply Max Weber's theory directly to Islam.

\section{NEGATIVE AND POSITIVE ETHICS}

Muslim ethics like those of the Catholic Church may be called "positive”. It is about God`s rewards. Man in principle will be saved, but he can forfeit his salvation.

Protestant thinking may be called "negative": it is about avoiding punishment. He must show something to his master, the Lord. The protestant must therefore be 
active, and even then he is not certain that he will avoid damnation. Now, there is a big danger for the Protestant. The more we do, the more active we are, the more possibilities are there to fail and thus to commit sins. And on top of this: sin may also lie in not doing the right thing at the right time. To omit the Good is just as sinful as committing the Bad. In view of the other world, the life of a Protestant is therefore obviously more dangerous than that of a catholic.

\section{SPIRIT OF CAPITALISM - ASCETICISM}

Wealth and riches may follow from our endeavours and from our being busy, but these are not the real aim. The bliss of working lies in the accomplishment of the well done work itself. Work is to the praise and honour of God not for my own gratification. The profit we earn with our master's gold is not ours. Lust and luxury is not what the servant should aspire to. The master will pay me what has been agreed whether I worked less or more than my fellow servant, viz. Matth. 2, 1 ss. Endeavour means to do more than is usually done, more than is absolutely necessary. Endeavour is work and labour at the expense of leisure and fun. So capital is geronnener Lustverzicht, the aggregate of forgone leisure \& fun or overtime turned into tangible worth. As bad breeds bad and good breeds good - as the proverbial saying goes - it follows that capital breeds capital, new capital breeds ever more of it. The more it grows the less we want to spend it - we want to invest it to increase it. Under the protestant ethics the investor does not want to become rich, he wants to show his master, that he is good servant.

It may therefore not be just a coincidence that the first Savings Banks, Sparkassen, were established in protestant regions of Germany. The idea behind these Sparkassen was very protestant: small earners should be given a safe, i.e. state guaranteed opportunity to invest their pennies saved and have them grow into capital instead of spending it. It was the same idea which led protestant Friedrich Wilhelm Raiffeisen $(1818-88)$ to found the cooperative movement and credit unions.

Let us take, under this perspective, a glance at the very rich: Who is there in Monte Carlo or other glitzy places? The Onassis type of people, tennis stars. You would not find Bill Gates there or Warren Buffet. Both are now in the process of setting up one of the biggest foundations ever to the benefit of underdeveloped countries. . Both are obviously behaving in a very protestant way, - whether they are believers and church goers or not the same is true with the likes of Mrs. Quandt, who owns the car maker BMW. The Albrecht brothers, arguably the richest people in Europe, are living in Essen, where the undersigned lives, who can tell from their neighbours that they are known for their parsimoniousness, but nobody ever heard of their big yachts, if they have any, let alone extravagancies. These billionaires are said to eat in the general cantina and to turn the light of, when they leave the room, and Warren Buffet is said to have not change his hair cutter in 50 years. 


\section{PROTESTANTISM OR WHAT?}

Like all big ideas Max Weber's theory has its critics. Be it enough to cite Max Weber himself: It would be stupid, he says, to infer that Protestantism was the only cause of capitalism or, even more stupid, to say that capitalism as an economic concept originates in the reformation.

There are also other reasons to stimulate activity. Times of war and duress can be seen as a stimulator to industrial progress. Is it really so that endeavours have something to do with religion or protestantism? Dubai has made tremendous progress in recent years. Is the Emir of Dubai a protestant? Malaysia has done rather well in many areas - are Malaysians protestants?

Well, yes maybe, in a way. Not in the religious understanding of this word, but in the sense which underlies protestant ethics and which ultimately may be also the spirit of the Quran.

The Quran teaches that God created the world not for sports; the Almighty intended to achieve something with this world, what is still hidden to us. God wanted men to contribute to this aim. Quran says that man should try to emulate God in his attributes. The sole aim of man is a progressive achievement of all divine attributes. The first and pre-eminent attribute of God is his being Creator of the world and of all what is within and without. This leads us to the conclusion that man according to the Quran may be destined to become a creator himself. I understand an Islamic mythos saying that God originally offered to the angels the divine trust, amanah, by which the world would have been transformed within and without into the likeness of the divine purpose. But these shied away in panic and terror. Then God entrusted this to man. Did we not also shy away from this? The practical ethic of a common Muslim is said to be quite the opposite of what Islamic ethics really are.

Thus we would infer that also according to the Quran man is under an obligation to actively emulate God in his "creational spirit". Man should try to improve the world and what is in it in order to conform it to the Almighty's aims as evidenced in the Holy Scriptures. Under this perspective, Islam would come very close to or would even coincide with what has here been described as protestant ethics. Maybe this ethic is neither protestant nor Islamic - it is just the common ground on which irrespective of our professed religion mankind stands, as soon we feel responsibility for ourselves and the world as a whole.

\section{CONCLUSION}

I wanted to show that religion, be it Christianity, Islam or others, is not a bed, in which we passively lie until we are led by the angels into paradise. Religion is a state of mind in which we out of responsibility towards God we make our own wings 
grow so that we may fly to heaven, albeit with His help. What can we do to make our wings grow and spread?

\section{LITERATURE:}

The Bible in the Kings James translation.

Aden, Menno

Christlicher Glaube (Cristian Credo) Münster 2004

Muhammad Ata al Sid

Contemporary Attempts at Overcoming Decadence and Revitalizing Quranic Thought

Business Review , IBA, Karachi, Pakistan, 2007, Vol.2. No. 1, p.72

Ranke, Leopold v. Deutsche Geschichte im Zeitalter der Reformation

(German History in the Time of Reformation)

This is still today the classical treatise on reformation, written between 1839 - 47; see also references in Wikipedia. .

M.M. Sharif, editor,

A History of Muslim Philosophy, 2 Volumes, 1963, reprint 1983, referred to as:

Sharif + name of author

Weber, Max

Die protestantische Ethik

Eine Aufsatzsammlung

Johannes Winckelmann, editor, 7.th ed. 1984

Wikipedia Internet Encyclopedia, English version, unless indicated otherwise

\section{REFERENCES}

Protestantism:

The term derives from the "protestation" on the Imperial Diet of 1529: There a minority of princes and free Imperial cities protested against a resolution of the majority led by the Emperor Charles $\mathrm{V}$ which forbade reforms in the church. The argument of this minority was and really is up to this day the very essence of Protestantism: In what concerns God`s honour and the salvation of souls everybody must account individually to God, and nobody can exculpate himself from this accountability by accepting a majority vote. Cf. Ranke. 
Modern democracy, contrary to common belief, was not invented in England. Italy, Germany and Switzerland, until 1648 a part of Germany, had republics, governing themselves and accountable to no king or prince, centuries before the first parliament in the modern sense was convened.

Sharif - Qadir Decline of the Muslim World,.., p. 1417 ss

Sharif - Mohammed Abduh, . S. 1498

Muhammad Ata al sid, loc. Cit., p. 57/8

Talantos (= talent ) used in this parable is the Greek word for a quantity of gold; cf. pound sterling, i.e. quantity of sterling silver.

Gib, dass ich tu mit Fleiß, was mir zu tun gebühret, wozu mich dein Befehl in meinem Stande führet. Gib, dass ich `s tue bald, zu der Zeit, da ich sll, und wenn ich`s tu, so gib, dass es gerate wohl. Evangelisches Gesangbuch - German Evangelical Hymnbook Nr. 492: O Gott, du frommer Gott.

Sharif, - Ibn Rushd, loc. Cit., S. 550

I hereby rely on: M.M. Sharif, Vol. 1, p. 199 ss (Mutazilism)

Sharif, loc. Cit., p. 150

Sharif - Mohammed Abduh, p. 1496

Muhammad Ata al sid, loc. Cit., p.69

Founded 1. August 1786 by Duke Herzog Peter Friedrich Ludwig of Oldenburg. T he oldest Sparkasse of the world, which is still doing business, and quite successfully so, is the Landessparkasse zu Oldenburg/ in protestant northern Germany, founded in 1789. cf. Wikipedia ( German)

Cf. Reference in Wikipedia

Sharif loc. Cit., p. 142

see Sharif loc. cit. p. 146

Ismail R. al-Faruqi, Science and Traditional Values in Islamic Society, Nr. 3 Vol. II, Sept. 1975, p. 235 -6 ( cited after : Muhammad Ata al sid - loc.cit. 
https://ir.iba.edu.pk/businessreview/vol3/iss1/13

DOI: https://doi.org/10.54784/1990-6587.1139

Business Review - Volume 3 Number 1

January - June 2008

"One remarkable variation in business ethics arises from the emphasis on individualism in U.S. culture as opposed to the emphasis on groups in many other cultures. Individualism in American social philosophy makes individual conscience the source of ethical control; the individual sin concept in Christianity makes personal guilt the penalty for bad conduct. But in other countries, a combination of the underlying factors discussed above has created far different ethical values.

The Japanese, for instance, have a strong ethic of fidelity to work groups and corporations. Beginning in about the sixth century Japan, like other Asian societies, began to borrow and adapt Chinese culture. Traditional values in China stressed that an individual's primary obligation was not to self but to others, including family, clan, and government. The Japanese also built a strong ethic of loyalty to superiors from the emphasis on fidelity in Chinese Confucianism. In medieval times the extreme of loyalty was seen in samurai, who gave their lives for feudal lords. Today it is seen in corporate employees who do ordinary jobs with life-or-death urgency. The concept of sin is foreign to Eastern religion and philosophy, so Japanese are not controlled by guilty consciences. Rather, they are shamed by group disapproval."

George A. Steiner and John F. Steiner

164 